\title{
es-cueto, o el ensayo como distinción
}

CARLOS SURGHI Universidad Nacional de Córdoba - CONICET, Argentina / carlossurghi@yahoo.com.ar

\section{Resumen}

El presente texto despliega una lectura del ensayista argentino Sergio Cueto. Partiendo de su último libro, Intimidad de las cosas (2018), es que nos proponemos relevar las diversas características del ensayo entendido como distinción, es decir, como modo de singularidad en la escritura. Para ello nuestro trabajo estudia la relación entre pensamiento y expresión, que en nuestro autor se evidencia no solo en sus libros más recientes, Cinco retratos (2010), Kafka. Una construcción (2009), sino también en sus primeros libros: Seis estudios girrianos (1993), Maurice Blanchot. El ejercicio de la paciencia (1997). Analizamos, entonces, lo que hemos identificado como orientaciones constantes en la escritura de Cueto, las que van desde su interés por el interrogante que suponen las cosas como pregunta filosófica, hasta la poesía entendida en tanto que expresión de lo real, pasando también por el humor como pensamiento de la extravagancia, o la música como advenimiento de una experiencia imposible.

Palabras clave: Cueto / ensayo / poesía / humor / música es-cueto, or the essay as a distinction

Abstract

The present text displays a reading of the Argentine essayist Sergio Cueto. Starting from his last book, Intimidad de las cosas (2018), we propose to reveal the various characteristics of the essay understood as a distinction, that is, as a way of singularity in writing. For this our work studies the relationship between thought and expression, which in our author is evident not only in his most recent books, Cinco retratos (2010), Kafka. Una construcción (2009), but also in his first books: Seis estudios girrianos (1993), Maurice Blanchot. El ejercicio de la paciencia (1997). For this we analyze what we have identified as constant orientations in Cueto's writing, which range from his interest in the question posed by things as a philosophical question, to poetry understood as an expression of reality, and also through humor as a thought of extravagance, or music as the advent of an impossible experience.

Key words: Cueto / essay / poetry / humor / music

Recibido: 13/5/2019. Aceptado: 29/7/2019

Para citar este artículo: Surghi, C. (2019). es-cueto, o el ensayo como distinción. El taco en la brea, 10 (junio-noviembre), 28-46. Santa Fe, Argentina: UNL. DOI: 10.14409/tb.v1i10.8683 
De niño, yo atesoraba lo que no entendía, lo que quedaba sin explicación, la gema rara que brillaba en medio de la ganga trivial de lo claro y sabido

César Aira

Solo el género ensayístico en su anacronismo voluntario y en su concentración altruista puede permitirse la siguiente observación propia de una inteligencia por demás irónica, elegante y atinada, cuando no absurda y malentendida hasta la sorpresa del sinsentido o el tropiezo con lo deslumbrante:

Evidentemente, todas las desgracias del hombre proceden de su incapacidad para quedarse tranquilamente sentado en su casa. Aquel que no sabe o no puede quedarse sentado es presa del desasosiego. El desasosiego es la primera desgracia, la desgracia a secas del hombre. (Cueto, 2018:65)

¿De dónde proviene ese relámpago de saber? ¿Qué paseo le ha otorgado el conocimiento de lo que afirma? ¿A qué cita — por recaudo o por pereza—jamás asistió su autor? ¿Cómo es posible, en tan pocas palabras, convocar a una comunidad de hombres que no salen de su casa, que piensan, sienten, ríen de melancólicos ataques por la gravitante presencia del sinsentido? ¿Cómo es posible, en esas escuetas palabras, convocar a residentes solitarios que escriben en la experiencia del «quedarse ahí», y que lo hacen para contrastar el rumor del afuera, la asistencia perfecta a la opinión, esa simple relación de ideas antes que la persecución estática de sus alcances con los cuales, los inamovibles, intuyen que se agota el mundo tras el artificio de una forma?

En esta licencia del ensayo está condensada la capacidad única de desplegar palabra tras palabra una aventura que va tras el ausente sentido. Dicha aventura no es más que lo que se reconoce como la tradición que nadie puede despreciar, el eco del que ya dijo, del que ya nombró y que ahora vuelve como lo nombrado. Pero también, en esa licencia está condensada la aspiración de toda escritura que se orienta hacia la intimidad de las cosas, y que no es ni más ni menos que divisar el primer instante en el cual, justamente, las cosas se vuelven el primer momento de su pronunciación, como si recién llegaran a girar con su peso en el orden de la sintaxis; como si todo lo que habita la posibilidad del ensayo pudiese ser visto e inmediatamente pudiese ser nombrado por ese hombre que se asoma al umbral de su casa, o que, desde su silla, dirige la mirada hacia la ventana entreabierta y, por más que nos pese y nos llene de cinismo, prefiere no salir, elige continuar su movimiento inmóvil.

Pero entonces, ¿qué hay en el pensar? ¿Un camino allanado por la reiteración? ¿La atenta mirada al misterio de los objetos? ¿El enigma de las cosas? Solo así con el desasosiego el pensamiento se vuelve ese movimiento inmóvil que la mirada melancólica orienta en una línea sin horizonte; y con el movimiento, que es más que el tiempo, el lenguaje no puede ser otra cosa más que un paseo por la tierra baldía de una tradición hecha de escombros inamovibles. Habría que observar entonces que solo un ensayista que aspira a la distinción solitaria de crear una lengua con los restos de la literatura, para así pensar en el ritmo de su invención los límites de la prosa de ideas, o aspirar a la transparencia de un mundo hecho a la medida de las figuras que convoca, solo ese ensayista obstinado y distante, atento y perdido en la continuidad de lo mismo, puede efectivamente sostenerse en el lejano y despoblado horizonte de su estilo. Ese ensayista es Sergio Cueto, y ha venido escribiendo libros de una belleza y un convencimiento radical. ¿Cómo hablar sobre ellos? 
Tal vez señalando la obviedad: son libros por demás extraños, son libros por demás secretos. Girri, Blanchot, Dante, Eliot, Kafka, Baudelaire han sido los nombres que no van más allá de una fascinante y monótona atención; pero también el tango, el humor, la seducción del pasado, la música como advenimiento, cierta inteligencia que solo otorga la literatura, han ido perfilando los alcances de verdaderos ejercicios de paciencia que, como no podría ser de otro modo, señalan una de las aventuras más interesantes de la prosa argentina en los últimos tiempos.

\section{II}

Bastaría recordar como prueba de distinción un pasaje del libro de Cueto sobre Blanchot, que ya se ha vuelto mítico no solo por la soledad con la cual llegaba en 1997, sino también por la apropiación de Blanchot, por la astucia para continuar escribiendo en él y afuera de él, más acá y más allá de la fascinación que genera el autor de El espacio literario, pero con la suficiente claridad como para señalar que la experiencia de Blanchot es una experiencia de extrañamiento e imposibilidad ante la vida; tal vez, la misma que experimentan los lectores selectos y solitarios que Cueto ha ido ganando con pasajes como el siguiente: «La desgracia es la experiencia del ser; no la experiencia de la imposibilidad del ser, sino la experiencia del ser como imposibilidad. La experiencia del ser es lo que desde siempre se ha llamado pensamiento» (1997:20).

Pues bien, señalábamos que bastaría este pasaje para corroborar la insistencia de un pensamiento, la reiteración obstinada, el merodeo imperceptible, profundo y silencioso con el cual Cueto ha venido pensando figuras tan poco comunes para el contexto de la prosa argentina que, desde ya, es imposible de pensar sin la gravitación ejercida por lo mejor de la literatura europea contemporánea y su tradición filosófica. Habría que detenerse aquí entonces para señalar dos astucias del ensayista. La primera es indiscutible: el arribo a lo sorprendente por medio de la forma, el avance de las palabras hasta amalgamar pensamiento y desgracia en la opacidad propia de la experiencia de la modernidad, o en todo caso, por medio de eso que deberíamos denominar estilo, o, mejor dicho - y con el empleo de una licencia soberana-cuetización del mundo, que hace de la lectura una desrealización por medio de lo escrito.' Ya sea ante Kafka y su misticismo de paradojas que Cueto va exponiendo una a una: «La habitación de lo inhabitable es la renuncia (Verzicht). La ética de Kafka es una renuncia. Renunciar es una tarea» (2009:43); o ante la experiencia baudeleriana del spleen como muerte del Ideal, que en definitiva no es más que un ideal degradado en leyenda: «La vida de lo que ya no vive, de lo que no ha vivido nunca, de lo que es incapaz de vivir: esto es lo que Baudelaire llama légende» (2001:65); o, porque no, en un punto más extremo aun: los tres chiflados y el encuentro disparatado de un humor seco y un rapto súbito del pensamiento que para su autor no es más que lo singular en lo disperso: «Tres no significa uno y uno y uno. Ninguna suma explica el tres. Con el tres empieza a decirse todos. Pero "todos" no designa la unidad masiva e indiferenciada en la que cada uno se anula sino una singularidad en sí misma plural, la singularidad de una multiplicidad o la reunión de lo disperso en su dispersión» (2010:127); es innegable entonces que Cueto accede a los objetos de su interés con un lenguaje despojado de toda referencialidad, pues solo se vale de él en tanto que, más acá y más allá de la crítica y la literatura que lo precede y lo funda, ese lenguaje es siempre invención de su decir; es también hospitalidad para toda palabra, empleo y uso de una expresión que devela el mundo como nunca hasta entonces se lo ha visto. O en todo caso, el lenguaje empleado por Cueto en su ritmo, en sus asociaciones, en su impulso musical de una verdadera Stimmung, no es más que esa 
aventura de querer salir del mundo cuando el mundo que se divisa está siempre suspendido en los pasos del afuera.

Pero volvamos a esas figuras del desasosiego y la desgracia que caracterizan a la modernidad como tal para marcar la segunda astucia del ensayista: hacer en el estilo el lugar adonde el pensamiento no puede apartarse de la forma, adonde el pensamiento, muy próximo a la literatura, no puede ser otra cosa más que la disolución de toda forma en el desarrollo de una forma. Como bien señala Blanchot la desgracia nos pierde, nos degrada, nos ciñe a la imposibilidad que no es otra cosa más que «pensar lo que no puede dejarse pensar» (1997:21). Sin embargo, ello no significa nada, no tiene sentido, carece de significado para el sujeto que lo padece; salvo tal vez en el nivel mismo del padecimiento, que es verse afectado por la desgracia, por la caída o el degradarse del mundo ya perdido. Esta fatalidad solo puede entenderse como negatividad pura, radical y sin extremo, pues lo que ansía no es más que el fin del sentido, el grado cero del pensamiento, la afirmación que en su fatalidad se hace fuerte y, por eso mismo, se presta a la más común de las frases: ipero qué terrible desgracia, por fin ya nada tiene sentido! Por eso mismo el lugar que Cueto asignaba a Blanchot era el lugar que aspiraba para sí, era el lugar del acontecimiento por desplegar antes que el lugar del sentido por validar o la verdad a corroborar; pues solo en el lugar del acontecimiento podría pensarse sin sentido el sinsentido, solo ahí, la literatura, se volvería la potencia negativa que, en vez de enlutarse ante el absurdo de la vida, se prometería como conciencia de lo imposible. Por lo tanto, el lugar de la literatura no es el lugar que ocuparía en el deseo de la comunidad, sino más bien todo lo contrario; su lugar es un lugar adonde ensayista y literatura se vuelven un estilo que acontece. A ese lugar de una singularidad tan particular podríamos entenderlo como el lugar de la desaparición moral de la literatura, pues justamente aparece como imposible de aparecer: «Pensar la desgracia es velar la desaparición incesante que no tendrá lugar, convertir al pensamiento en el lugar de la desaparición sin lugar y así, tal vez, en el lugar de la desaparición de la desgracia, la inapariencia de la literatura» (7).

¿Se ha vuelto imposible pensar? ¿Solo lo imposible es posible de pensar? ¿Qué resulta ser el acto de pensar? Pensar es hacer que lo aparente de una imagen, un nombre, algo que se ha oído desaparezca; que en la superficie de las cosas destelle el brillo de lo singular por medio del cual estas se vuelven cosas; pensar es hacer que aparezca aquello mismo inaprensible en las cosas por ser absolutamente indiferentes hacia cualquier intencionalidad. Se trata de un paso indiscernible pero certero: sumirse en el fondo de lo no caracterizado. ${ }^{2} \mathrm{Al}$ irrumpir las simples cosas del mundo en nuestra intimidad, al ser ellas las preguntas y las respuestas para el movimiento o la quietud del hombre que las ve, ya los objetos nos han abandonado; hemos renunciado a prestar atención a ellos pues son meras entidades transparentes, superficies pensadas adonde lo aparente no desaparece, sino que más bien ya se ha vuelto fijeza. Que la literatura realice este sueño del pensamiento es posible gracias a su carácter impersonal, a su autonomía y a ese lugar del estilo que así ocupa y sustrae a la continuidad del mundo. En diversos momentos Cueto ha entrevisto los lugares de ese estilo, los nombres que lo nombran, las imágenes que se oscurecen cuanto más se quiere ver en ellas. En el ensayo esta atenta mirada no es más que un hacer consciente la enajenación del mundo; no es más que un repliegue profundo que va, desde la consabida y tranquilizadora relación sujeto-objeto - a la que Blanchot llamaría reducción hacia esa afirmación en la que se señala que «la cosa no tiene lugar en la representación, es irrepresentable para el sujeto» pues, efectivamente, al huir de la reducción del pensamiento, al seguir siendo aún sin nosotros, 
«las cosas están solas, solas como ningún objeto lo estará jamás» (2018:39)—; y a esa soledad, es necesario llamarla indistinción. Y una vez más, en ella el ensayo se nombra por hacer de su resistencia indistinta, la distinción no reductiva de su forma.

\section{III}

Los ensayos de Cueto poco a poco se han vuelto el lugar del estilo adonde la acción de pensar no es más que la irrupción del asombro ante la indiferencia. Se trata entonces de ensayos que buscan un saber que no sabe, pero a la vez, que no pueden dejar de asombrase ante esa indiferencia que encuentran en el saber del asombro. Lo que el ensayo busca — como hace tiempo ya viene haciéndolo por vía negativa a la verdad, por resistencia ante la ciencia, o por desenfado para con lo académico - es llevar el pensamiento hacia la experiencia del arte, ese punto de intimidad que lo disuelve todo a nivel de procedimiento, método, autoría:

La rosa no es para nadie, o lo que es lo mismo, es para nadie, es la rosa de Nadie. Solo la mirada de Nadie ve la rosa. Por eso el arte, si es que arte quiere decir, en primer lugar, experiencia de las cosas, supone o aun consiste en el devenir Nadie del artista. Giotto, Cézanne son pseudónimos o heterónimos de Nadie. (2018:40)

Solo la indiferencia en la cual las cosas se dan para sí y para el sujeto puede volverse conciencia. Podríamos entonces decir que el hombre sentado, el solitario, el meditabundo paseante, todas y cada una de estas figuras recogen al mundo y a sí mismas en la impasible silla que las recibe, en la calle abierta que las espera, en el lápiz silencioso de la anotación adonde reparan antes que en el fastidioso culto de la personalidad al que rehúyen.

El rehuir al cual Cueto somete el lápiz con el que se escribe, la calle en la que se camina o la silla en la que se descansa debe entenderse como un recurso propio del ensayo que, por cierto, es ambiguo. Aquí la consabida distinción de objetividad y distancia con la cual se funda un discurso argumentativo no es más que una inflexión del estilo, pues, por sobre la distancia que el rehuir propone, se puede también leer lo singular, lo propio del ensayista, aquello que hace a su intimidad, aun cuando esta sea insondable. El rehuir es entonces el volver artificio la intimidad; el transformarla en método objetivo de una pasión tan subjetiva como lo es la escritura. Tomemos por caso dos figuras en una misma frase, el baldío y el tapial. Nos permitimos en la cita leer primero lo meramente literal que hace al rehuir de la argumentación:

\footnotetext{
Alguna vez se intentó abstraer del desperdicio un residuo, salvar todavía el residuo en el desperdicio, iluminar, aunque más no sea un instante, por ejemplo, los pedazos de una botella rota tirados en un baldío o alineados en la cima de un tapial, y entonces se descubrió la triste maravilla de la vida en una epifanía vana. (50-51)
}

En la primera lectura es innegable la deuda que se tiene con Eliot y Borges al rehuir por medio de las figuras mencionadas o, como le gustaría decir al primero, por medio de los correlatos objetivos que convoca; pero en una segunda lectura, que corre hacia lo íntimo, o, mejor dicho, que nos devuelve a la imposibilidad de la intimidad, algo se filtra, algo expone justamente lo rehuido por medio de la expresión triste maravilla, la cual, hace del baldío y el tapial, la patria barrial de 
la infancia. Es indudable que lo que Cueto llama epifanía vana, aquello — sea lo que sea — que se precia de ser tal, pertenece, para ser eso que el ensayo dice que es, al orden de lo autobiográfico en la escritura. Como tal, ella está hecha de una oscuridad que indudablemente se pierde y se hunde en el fango de lo biográfico, en donde solo la peripecia y el empleo de otras figuras, el destino constelado en el cual se traman, puede iluminar o nombrar, pero jamás equiparar o definir. Por lo tanto, una distinción y una pertenencia a la inmigración de principio y mediados del siglo XX, junto a un provincianismo de la llanura-urbana, que en términos musicales podría traducirse en el ritmo marcado de Pugliese y su orquesta a fines de los años treinta y mediados de los cuarenta, acaso condensable en la figura de un recuerdo en el fango de la infancia, corrobora la visión de botellas prolijamente apiladas en la cima de un tapial como verdadera Beleuchtung de esa infancia, o epifanía vana que, solo el estilo, puede traer nuevamente al presente.

De este modo, lo que Cueto denomina «la impersonal conciencia de la cosa», no es más que un saber que se vuelve escritura, todo lo que acontece por «obra de un estilo». Sin embargo, la pregunta por el hacer de las cosas, que no es más que la vieja pregunta por la impersonalidad de la literatura, termina siendo pregunta por la naturaleza del ensayo, por la orientación a seguir en su destino que busca una forma: «Es preciso encontrar el estilo de la cosa —¿cómo se despierta la calle?, ¿cómo corta el cuchillo?-, pues es el estilo el que hace la experiencia de la cosa, es en el estilo que la cosa es experiencia» (43). Si el estilo es la forma que responde a la pregunta que la cosa plantea, la impersonal conciencia de la cosa no puede reducirse a una simple descripción, a un relevamiento del saber cuál estadio de una idea; en este caso el despertar de la calle o el cortar del cuchillo, como interrogantes o desgracias del pensamiento, son mucho más que acciones propensas a una fijeza, a un modo de ser dichas, a una reducción que, en el espejismo de la medianía, encuentra la calma límpida de toda transparencia. Opacado por su ser de pregunta el estilo se vuelve experiencia solo en tanto es un modo de ver la intimidad de las cosas. Aunque este hacer saber del estilo no se trata de una asimilación o una impostación del discurso crítico. En verdad, todo saber de la cosa es literatura; pero literatura que otorga un saber en tanto que este no va más allá de la frase, pues la frase es ese saber buscado por la literatura: saber de lo que es en tanto que es, y no en tanto que simula estar ahí puesto en lugar de por otra cosa.

Hay una soledad de la frase en Cueto a la cual solo se llega por medio de la paciencia como ejercicio. Dicha soledad asegura una continuidad del pensamiento, resguarda su potencia en el instante mismo en que revela su impotencia, instante en el cual se sobrepone a la doble acepción del nihilismo que tiñe la contemporaneidad: que nada haya y que el valor se suspenda para que todo pueda ser. Esa soledad persigue lo imposible, lo que no se puede negar ni decir, lo que Wittgenstein señaló como el límite a la nada en el «que es de lo que es»; y que Cueto señala como lugar de lo habitable, del reposo, del tedio, de la atención a la cual se encamina el ejercicio por medio de la paciencia y la soledad que toda escritura demanda. ${ }^{3}$ Por lo tanto, allí adonde podríamos leer un resquemor acético no hay más que una simple felicidad, un lucimiento por lo bajo, la prepotencia para que una idea triunfe en su despliegue. El ejercicio es entonces la inmovilidad que se ahonda escribiendo de un modo sostenido y paciente; es el salir sin dejar de estar sentado, el viajar sin cruzar la puerta de nuestra casa. ${ }^{4} \mathrm{Y}$ es que la paciencia no es más que cierto holgar empleado a favor del ensayista. Se trata de una permanencia en la pasión que generan ciertas formas, una insistencia que Cueto lee como continuidad y cambio en algunos autores que han ido forjando un fantasma del estilo. Por caso, lo árido en Girri, lo paradójico en Kafka, lo vulgar en Eliot. Por eso 
mismo no hay nada más solitario que el estilo, porque convoca a pocos y los prueba en la soledad de una insistencia sin desvío: «Holgar no quiere decir abandonarse, entregarse ociosa, floja, blandamente a las circunstancias; holgar quiere decir permanecer perseverantemente en la simplicidad sin desviarse un punto. Holgar quiere decir permanecer en la imposibilidad» (1993:55). ${ }^{5}$

Habría entonces que señalar que hay una medida del holgar en la permanencia de lo simple, y es la escritura que no se fuerza, que transcurre según lo que la paciencia dicta en el no desviarse un punto del ensayo: hoy se escribe una línea, un párrafo, una sola palabra; mañana, tal vez, no, apenas poco, casi nada, pero en una misma orientación. La frecuencia de dicha permanencia la establece la notación final de los textos, insistencia en la que Cueto marca un gesto. Por ejemplo, en Versiones del humor encontramos textos escritos en 1990 que se editan en 1999, y que descansan o conviven, en su reescritura o en su espera con Maurice Blanchot, concluido en 1996 y publicado un año después, o con el libro dedicado a Girri, que sale en 1993. En Cinco retratos, publicado en 2009, el ensayo titulado «El tango», reza en su última línea: «julio 1999-noviembre 2008». ¿El ensayista abandona sus temas? ¿Los temas expulsan al ensayista? No, en realidad tanto uno como otro permanecen en la holgura que producen, solo ella puede abarcar lo extenso y extraño de una forma; solo en la holgura se da el lugar de la interrogación. En Intimidad de las cosas, último libro publicado hasta la fecha, leemos: «Las cosas tienen lugar en el pasado. El pasado es el tiempo de las cosas. Si el objeto siempre está presente ante un sujeto, el estar de la cosa tiene la forma del pasado, es decir, del sido ahí» (45). Mientras que — ¿veinticinco años atrás? — en el libro sobre Girri se leía: «La cosa, dice la memoria, es en la forma del pasado. La cosa, la íntima realidad de lo que es, lo que es en su realidad más íntima, es, se da a nosotros, como la forma del vacío» (6o). El ejercicio vuelto paciencia - y aquí habría que entender la paciencia como un no desvío, un no apartarse, un apego a los temas y su borramiento del tiempo o una fascinación silenciosa - asegura una permanencia en la interrogación, vuelve de algún modo más llevadera la desgracia del pensamiento. El ensayo piensa entonces no para acabar con las cosas, sino más bien para hacerlas una con nuestro destino, ya sea este pura pulsión de escritura o melancolía de la holgura.

El holgar es un desenfado positivo respecto a la retórica que se afana de un uso correcto del impulso con el que la escritura se vuelve forma y, justamente, forma transparente, aséptica y objetiva. Por eso en la crítica entendida como doxa no hay destino posible, pues nada persevera, nada aspira al principal objetivo del ensayo: la distinción. He aquí por qué entonces la soledad del ensayista no puede renunciar a la negatividad redentora del holgar. Solo el holgar, cual un dandismo de las ideas conduce en la ciudad letrada hacia un instante de experiencia de lo leído. Solo el holgar preserva de lo presuntamente útil que busca hacer del pensamiento una utilidad, una aplicación. Así el despojo de todo método evidente, la llaneza de referencias auxiliares en donde ver un sistema o una orientación, y hasta el casi nulo régimen de citas en donde el discernimiento entre objeto, corpus y discurso se disuelve, terminan forjando en la escritura de Cueto esa distinción particular: la presencia de lo escueto. Lo escueto es el deseo de un grado cero en relación con la mediación; lo escueto es el convencimiento de que, lo real que interroga, solo hace lugar a dicha interrogación en el espacio del lenguaje y el arte. Y es que lo escueto esconde una sentencia silenciosa: a la experiencia de lectura le sigue necesariamente la experiencia crítica. Pero para que dicho espacio de experiencias que se suceden sea posible es necesario que la paciencia y el ejercicio lleven a la soledad de la frase. A ese nivel la frase ya no es más que imagen y ritmo, una estructura casi invisible en cuanto a referencialidad que se sostiene en la pura ejecución de su acontecer. Por caso la pregunta 
que la antecede y la precede es cómo hacer una experiencia de Eliot; o cómo, aceptando la fatalidad de la mediación, burlarse de ella en el impulso que acompaña a lo escrito, al ejercicio — solitario y paciente - del estilo: «Así como la reflexión llena el desierto del pensamiento, del mismo modo la charla colma las tinieblas de la palabra» (2001:79). En la escueta frase he ahí todo Eliot, el del ingenio metafísico, el de la apropiación de la tradición, el de la vulgar música del presente. Lo está por debajo de desierto y tinieblas, pues ahí el sentido ya no se viste de sentido, sino que más bien se prueba el poder de evocación que vio en la experiencia literaria, en el primer deslumbramiento de la soledad. Solo la paciencia del estilo traerá de vuelta ese deslumbramiento. Duplicar ese deslumbramiento llevará tiempo, deberá trabajarse en la holganza para que en la paciencia y después de ella este acontezca; tal vez por eso la frase no solo evoca figuras sino también la sorpresa de la paradoja en su aspiración por revelar un saber o experiencia completamente desacralizado por la risa, la nostalgia, el ingenio, la pura sorpresa que hace uso del lugar común y que a la vez lo disuelve: «El tango empieza cuando todo ha terminado. El tango propiamente no empieza, sino que termina, no hace más que terminar» (2010:13-14). La frase es entonces en Cueto no solo un registro particular de la asimilación de una tradición y un uso de esta para que el estilo pueda ser destino en la escritura, sino también lo distinguible de ese estilo, la señal con la cual una soledad nos habla desde los desplazamientos inmóviles con los cuales se acerca a la intimidad de las cosas.

\section{IV}

Solo la indiferencia de las cosas puede hacer que la conciencia se vuelva reflexiva, aspire a saberse distinta, emprenda ese camino que, en definitiva, no es más que un alejamiento de la naturaleza en procura de desplegar una aventura del espíritu. Aun así, las cosas no dejan de ser un enigma, no dejan de habilitar el lugar para la pregunta, la insistencia de lo que es, esa especie de proximidad a lo misterioso que repele y fascina. Por eso la cerrada indiferencia de las cosas es la abierta expectativa del pensamiento, aunque de un modo particular, de un modo que busca superar cualquier escisión, cualquier diferencia en opuestos que se tensionan. Entre las cosas y la conciencia no solo hay un vínculo que es reductivo, el que aparece ni bien la cosa es degradada a su categoría de objeto; ${ }^{6}$ sino que también hay un vínculo más que estrecho en tanto que, las cosas, habilitan un autoconocimiento: «El hombre adquiere conciencia de sí mismo y del mundo solamente en la cosa - en la calle o la manzana, el jarro o el umbral, el barco o el cuchillo. La cosa es el lugar de la conciencia del hombre» (2018:43). Pero para que las cosas sean ese lugar de la conciencia es preciso que sucedan, no como vienen sucediendo, en su quieto mutismo o en su reducción a objetos que tal vez utilicemos o simplemente devengan desechos, sino más bien como un saber que acontece, como un hacer que las convoca. Traer a las cosas por medio de ese hacer para que estas sucedan en lo inmediato, no es más que cargar el presente con preguntas que lo interpelan, que lo transforman en pasado, que lo vuelven el lugar de la pregunta:

Es cierto que las cosas están siempre ahí, ya están ahí antes de que uno llegue. Es como si su tiempo fuera el pasado, como si el hacer tuviera que sacarlas cada vez de ese ensimismamiento absorto que es en ellas la presencia de un pasado incomunicable. Por eso ha podido decirse que las cosas son lugares, que cada cosa es un lugar. La cosa es en cada caso el lugar del suceder. Hacer es hacer que el mundo suceda en la cosa. (2010:63) 
Por lo tanto, si las cosas tienen algo que decirnos, si su indiferencia nos habla, si en tanto que lugares llegan a un determinado lugar para ponerse próximas a nosotros, ese acercarse desde y hacia lo lejano lo hacen por medio de la literatura; he aquí que llegan a ella pues la indiferencia de las cosas solo puede soportarse - en tanto enigma o en tanto pregunta - en el espacio de la literatura, más precisamente, en la poesía, el lugar adonde «lo real se hace palabra» (63).

Existe un más allá de la desgracia, del desasosiego; y no es más que una voluntad por afirmar lo que existe, ya sea eso un tapial con botellas, un umbral adonde se acumula la basura, o el misterio del sabor de una manzana. Para Cueto el poeta de la dichosa afirmación es Girri, en él «la poesía es intensificación de la vida, exaltación de lo que la vida tiene de más precioso: sobrepasarse a sí misma» (119). Como nadie Girri ha podido hacer del habla un gesto de atención, ha podido sobreponer esa habla, que se vuelve estilo, a una divagación en el mundo que no es más que restos de lirismo. Por eso atender a lo real —exigencia de la poesía que Cueto señala en Girri—no es más que apropiarse de lo circunstancial; es hacer el poema con «la prosaica inmediatez de lo cotidiano», como lo señalara Donne; y, por lo tanto, todo estilo en poesía, que no es más que «la realización de lo real", será metafísico antes que anecdótico, estará del lado inesperado de las cosas antes que del lado presumible de «las expansiones melódicas del yo». Que lo obvio sobrevenga como lírica aun en lo que hay de tautológico en poesía, que las superficies se vuelvan más profundas que lo allende, o que las palabras para sobrepasar la vida se resalten en su insignificancia, pues no hay verdad a no ser en su sintaxis cuando se subleva como música, parece ser lo que Cueto lee en Girri como poeta de las cosas, como mente aplicada a un puro devenir indiferencia que busca definir el hacer del lenguaje con el que se gesta el poema:

Pero hay también que enfriar la expresión, apagar su natural patetismo con la más contenida inexpresividad, su visceral garrulería con el más mesurado laconismo. Para impedir que la lírica se convierta en una cantinela infinita, una anodina exaltación del bullicio es necesario que el habla se seque como una rama, se inmovilice como una piedra. (80-81)

Por lo tanto, si las cosas eran el lugar para la conciencia del hombre, la poesía, que en este caso no es más que forma - y entendida como construcción en donde «lo real se vela» (35) en su simpleza y contradicción - es el lugar de los objetos, la infancia de todas las preguntas; la poesía es entonces como lugar y como pregunta la proximidad de lo lejano.

Entre las cosas y el poema se traza una experiencia negativa que consiste en sobrepasar la mediación del lenguaje, en entrever una expresión futura hecha de una música inaudible. ¿Cómo nombrar aquello que niega el mismo nombre? ¿Cómo llevar a las palabras la indiferencia misma de las cosas? En la gravitación de estas preguntas se juega dicha experiencia y, para Cueto, Girri hace de ellas el gesto que funda su poesía. ¿Qué dirá el poema? ¿En qué tema encontrará su justificación de ser? En realidad, la poesía de Girri responde siempre con un principio de intransitividad; antes que la transparencia de su época, o la consonancia con su tiempo, el poema desea la afirmación de sus gestos negativos: «El poema es gesto. A diferencia del acto, el gesto es indiferente a la significación. Esencialmente intransitivo, él solo dice que es (...) El poema no tiene nada que decir (...) se limita a gesticular (...) el gesto proviene de la inmediata lejanía de la soledad» (16-17). Si es cierto que "se llama cosa precisamente a todo aquello que no accede a sí», y si esta está arrojada en esa lejanía de la soledad, pues «la cosa no sabe qué es porque ni siquiera sabe que es» (2018:41), 
entonces el poema no es más que la posibilidad de que las cosas se encuentren en la vida. En la lectura de Cueto, Girri es por cierto el poeta de lo arduo, no tanto por todo aquello que puede haber en su expresión, en su rigor y hasta en su oscuridad, sino más bien porque entiende que la poesía no existe sin las cosas, y solo las cosas preservan al poema en tanto es el acontecimiento de un lenguaje en el futuro. Pero también la poesía excede a Girri; su estilo y su sintaxis no son más que episodios de esa orientación futura en la cual, la música, la pura opacidad de lo abstracto, es su máxima realización. ${ }^{7}$ La reflexividad del poema, el hacia dónde la sintaxis de Girri lo lleva, es otra forma de la intransitividad. Su objetivo no solo consiste en que el poema se piense a sí mismo en lo que es, sino también que se afirme como pensamiento, como gesto de un impulso. Por eso el poema ya no puede ser entendido solamente como un objeto estético, pues en él se tejen toda una serie de operaciones de la mente que hacen a su devenir de cosa. En definitiva, se trata ni más ni menos que de escribir pensando la escritura justamente como nada, para que así, de ese modo, solo sea un verdadero escribir aun en el límite mismo de la poesía. Esa es la orientación hacia el silencio que toda escritura lleva consigo; orientación que va más allá de la estética porque ya no se nombra como composición, práctica o escribir si no una vez más como ejercicio: «Por eso la poesía es también, y no en menor medida, el descanso, la calma del camino, el ejercicio que se afirma sin ejercerse» (1993:122). ${ }^{8}$

Cueto ha observado alrededor del poema las posibilidades del pensamiento de la cosa; pero más que eso lo que importa es el lugar que el poema reconoce como tal; que reconoce como tiempo, percepción y experiencia de la cosa, es decir, como las coordenadas que hacen a la infancia de las cosas. Baudelaire predijo la transformación de estas; primero en su fisonomía de mercancía al ser lo que abunda en su forma de objeto, lo que terminamos nombrando como indistinto; y luego, como un acumularse del mundo en la esterilidad de esas formas que caen en desuso, que son olvidadas, que ya no cotizan para nadie, que se vuelven deshechos. He aquí entonces que Baudelaire le dio voz a su lento desaparecer, a su arruinarse; entrevió el eclipse o el derrumbe que significó su lejanía, su exilio en el Ideal y el descanso del Ideal en la tumba de su degradación. Por eso sus alegorías no son más que la última correspondencia para con la lejanía de las cosas; luego de ellas apenas si alcanzará el destello del ingenio uniendo imágenes que están en constante movimiento para intimidar a esa lejanía, para traerla de regreso. Lo perdido se transforma en reino, en él las cosas no son más que antiguos títulos de una aristocracia que se desvanece. Aun desconociendo el tango, Baudelaire evoca esta lejanía con la premonición de su música; ya están ahí el fango, las afueras, el barrio que cambia, una diosa y un cisne, y en esos lugares la quieta expectación de las cosas que se han perdido como tales en esos escenarios, en esas mascaradas alegóricas; sólo de ese modo puede Cueto leer la cifra que se oculta en la muerte del Ideal, solo así puede entender que el tango y la poesía son un modo de mirar lo presente-distante:

El recuerdo es la familiar mirada que llega desde la lejanía del Ideal en las cosas. La cosa mira desde la lejana patria del Ideal, desde lo natal. La mirada pone lejanía en las cosas. No es que ellas se vayan lejos, o no solo eso; es la lejanía la que se recoge en las cosas, son las cosas las que se convierten en la intimidad de la lejanía. (51)

¿Qué mira entonces la poesía? Aquello que en la ruina del presente no deja de hacer gestos hacia el pasado de las cosas. La poesía mira entonces esa lejanía del presente que se trama en 
esa forma a medio camino de la representación y la descomposición. La poesía mira el lugar del pasado que está aún en el presente en una forma que pertenece y no pertenece al tiempo, pues más bien es lugar adonde el pensamiento se aplica: «Solo como ruinas las cosas y los seres (balcones, esquelas, viejos) están en el pasado, encuentran su lugar en el pasado y el pasado se convierte en lugar» (65).

Pero ¿por qué el presente se llenaría de pasado, y más aún en una epifanía vana hecha de desechos, restos, trastos que son su espejo de lo vulgar? Aquello que en el mundo se vuelve ruina atraviesa dos instantes: el del lento derruirse, y el de la inmóvil sustracción al progreso. Ambos conforman un modo de permanecer en el mundo; en un mismo momento lo que se deteriora llama nuestra atención por su decaer, y a la vez, pasa desapercibido por ausentarse del uso que hacemos de las cosas. En la experiencia se trataría de puertas por las que ya no pasamos, cuchillos que ya no cortan, botellas en un tapial que brillan sin su oscuro contenido; pero aun así habitan como tales en nuestra percepción, nos traen al presente su gastarse de cosa. En el recuerdo las ruinas adquieren entonces la pátina distintiva de lo decadente; están en el presente, pero nos devuelven al pasado, y están y no están en ningún lado. Sin embargo, cuando la decadencia se vuelve cotidiana, cuando chocamos con ella y en ella ya no vemos ese recuerdo de un antiguo esplendor, las cosas se vuelven vulgares, pierden sustento en la historia y se deshacen en formas irregulares cual manchas en el piso que mudas reclaman por lo desaparecido: «La vulgaridad habrá de recordarse, si se recuerda, como el vacío dejado por la desaparición de la decadencia» (72). Por eso lo real que la poesía eleva hacia la forma carece de deseo, tiene atrofiado los sentidos, lamenta la vitalidad perdida para cantar así la nada que lo alimenta todo. He aquí el paisaje de Eliot, el cual Cueto nombra con palabras como desierto, tiniebla, y que hacen a la poesía, que es más allá y más acá de la tierra baldía; pero también, el paisaje en el cual las cosas harán señas ya no al poeta, sino más bien a la impersonalidad como disposición de la forma. ¿Qué hará la impersonalidad con las cosas que encuentra en el desierto y las tinieblas? ¿Dónde irán a parar los trastos, el ser-ruina de las cosas en la melancolía del cuartito del fondo del poema? Vestido con su raído traje de la impersonalidad, hurgando en los basurales del lenguaje, en los restos y desperdicios de la literatura, el poeta como ciruja entona su elegía; no queda otro estilo más que el estilo perdido en medio de todo lo perdido, lo que se ha desechado, lo que inunda un presente a la vez vacío y repleto de vejez; ahí, en la corona de las ruinas, la vana epifanía le dicta al poeta:

\footnotetext{
Alguna vez se entendió que con la pérdida de las cosas venía la pérdida de los nombres y que solo quedaba la abstracción de la sintaxis, pero se entendió asimismo que la sintaxis era lo que quedaba, es decir, lo que quedaba de ella, que ella misma estaba en ruinas, que el desasosiego ya trabajaba en ella, sobre todo en ella, de manera que tal vez había que encontrar precisamente en el desasosiego de la sintaxis la sintaxis del desasosiego, la música quieta de la más pura inquietud. (2018:51)
}

\section{V}

¿Cómo restar entonces gravedad a lo vulgar que se ha vuelto desasosiego, desgracia, el lamento insostenible por las cosas? ¿Cómo anteponer a la sintaxis de lo grave una forma de lo leve, un paso de baile lo suficientemente ridículo como para destacar la estela dejada por la risa en el instante mismo en que el mundo es puesto patas para arriba? Los estudios sobre el humor de Cueto deben leerse como una continuidad y una contracara de la vulgaridad. $\mathrm{O}$ en todo caso, por los pasajes 
de lo vulgar, lo vulgar mismo llega a la encerrona que solo se supera con la carcajada, el gag, la extravagancia, el sinsentido liberador. Cual un salto místico —en tanto que lo vulgar se vuelve ridículo - el humor se transforma en el punto tolerable del mundo cuando este se precipita hacia lo inhabitable; el humor es ni más ni menos que el punto extremo de toda lógica, el reverso de todo sistema de pensamiento al cual las cosas han sido arrastradas por la vigilancia de la razón: «Ahora bien, sostenerse en lo insostenible, habitar lo inhabitable es la definición misma del humor. Por eso el humor es un salto y el salto místico una cabriola, un disparate, una bufonada» (2008:17). El salto del humor nos deposita en "la inmanencia rota de este mundo», y cuando la razón señala la presencia del absurdo, antes que el lamento - ya en el aire, ya en la voltereta - el principio de insensatez nos invita a jugar, bailar, pasear por el país de las maravillas donde la locura es un hábito y no una falta o una negatividad: «El nonsense es un hábito loco, delirante, pero su locura es un hábito. Por eso constituye el único modo de habitación de un mundo que ha mostrado ser inhabitable» (15). Solo así el basural y el cirujeo del poeta se transforman en un jardín de delicias y una invitación a tomar el té; por acción del humor toda jerarquía se desquicia, todo pedestal se cae cual si le hubieran quitado su silla en un baile loco; $y$, finalmente, es el hombre quien pierde la gravedad de lo serio al quedar patas para arriba riendo en el arte de habitar la posibilidad de un juego, lo que Chesterton señala como «la experiencia de la constate infancia del mundo» (22), lo que se debe recuperar para plegarse a la ligereza. Sin embargo, para no quedar en la aridez o la esterilidad de una forma cuya finalidad y efecto están aseguradas, para no quedar en lo propiamente estertóreo de la carcajada, o, en el fondo moral de lo satírico grotesco, el humor debe olvidarse de juzgar, debe conservar esa irreverencia del misticismo que es salida de sí, abandono ante lo extraño; solo así el humor es reflexividad sin fin, exposición y despliegue, lo que Cueto llama «incasable alegría» (25).

Las versiones del humor de Cueto escapan entonces al efecto de la risa, pues el humor antes que un objeto es un procedimiento, una forma de la inteligencia extrema en el mundo. Así el humor, en tanto que cosa, es el lugar de la lejanía, la extraterritorialidad que resplandece cuando la razón traza los límites de la sensatez. Los países exóticos de toda búsqueda, el detrás del espejo como resguardo de la maravilla, y hasta el viaje o un simple paseo cual un desplazamiento sin destino ni origen, es decir, como puro trayecto, no son más que mapas o territorios en los cuales la extravagancia se despliega como forma de ejercer la inteligencia. Por lo tanto, Carrol, Lear o el mismo Swift o Walser, para Cueto no son más que extravagantes, es decir, versiones de la singularidad, subjetividades que están fuera de lugar, al margen del juicio del mundo, en el destierro de lo incorrecto y ejercitando «el prudente habito de la desmesura» (45). Hay entonces algo de utópico en el humor; pero no a nivel de organización tras una corte o un parlamento de insensatos, sino más bien a nivel de forma, pues la sátira de Gulliver lo comprueba hasta el punto de diseccionar todo lo posible del mundo y no hallar en él más que inmundicia, el resto diurno del temprano sueño de la razón. Tanto el llanto como la risa son realizaciones del estilo; no solo por la singularidad que individualizan, sino también por la sustracción que suponen. ¿Qué hace con su risa el que ríe? Por supuesto, la risa es como el viaje; no tiene origen pues se puede reír sin motivo, y también carece de destino, pues no conduce más que hacia la fuga, la tensión desperdigada por el estruendo de la carcajada. La risa es el lugar utópico de todo estilo. Habría que pensar los ensayos de Cueto como fugas de lo escrito en el trayecto irreducible de la risa, en el rapto de lo incorrecto que el humor propicia al ser el lugar por afuera del lugar de lo esperado: «la obra de Chejov es un tango 
cuyos protagonistas son Los Tres Chiflados» (100). Solo así el pensamiento recupera su condición de discernimiento alegre, solo así la inocencia puede ser ciencia pues «desprender la comicidad de la desgracia exponiendo la desgracia en la comicidad es la tarea del humor» (99). ${ }^{9}$ De este modo el salto pantomímico del humorista, al igual que el estilo sonriente del ensayo, no son más que elevaciones de la gracia, la pura inocencia de un ejercicio que busca recuperar un saber perdido de las cosas, acaso la penosa o ardua tarea de no hacer nada, a la cual, eufemísticamente, llamamos literatura. En esa persecución del estilo que ríe podemos leer la melancolía de un retorno imposible al bien; podemos leer un deseo de borramiento en el lugar adonde justamente se inscribe la separación que el conocimiento ha producido, pues, como Kafka lo señalara, «solo el mal tiene conciencia de sí mismo» (78); por lo tanto pensar después de la desgracia es irremediable, no solo por lo que en ello hay de vano, sino también porque no queda otra cosa por hacer, salvo la aceptación de lo irremediable que llega cuando lo entendemos como irrisorio. Solo así la escritura, el humor o la locura de la razón pueden hacer de la desgracia una aventura, un viaje en el cual un paseante dice a toda desavenencia que sí, pues sabe que, cualquier catástrofe del destino, no es más que una afirmación humorística, lo ineludible en tanto que «la obra artística es la experiencia de un diálogo entre la desgracia y la alegría según la distancia de lo irremediable» (1999:15).

Nada más leve entonces que el desamparo, al menos en los términos en los que Cueto lo opone al poder: como reflexividad del humor, como simple pulular de la tontería ante lo grave; cual un fluir de palabras encadenadas a la atención de una niña, quien contempla la intemperie de lo abierto en la imaginación de Carroll, en el viaje sin mapa, en ese país sin horizonte tras el cual se parte a la caza del Snark sin saber muy bien qué es un Snark. Solo así existe la posibilidad de una infancia, lo que Cueto define como «nuestra última imposibilidad» (33). ${ }^{10}$ Resulta que como «caducidad de la consistencia» la infancia se disuelve en su risa, su loco ir de aquí para allá, la atención que se pone a la minucia de la extravagancia; pero también en su tristeza, la infancia se disuelve en su puro ser de desamparo, es decir, de intimidad expuesta en la intemperie. Por supuesto que, en el viaje, en la persecución de la caza no hay punto de madurez posible; la fuga hacia adelante consiste en hacer del desamparo un juego, enfrentar con lo irrisorio lo irrisorio mismo de esta condición, ya que una y otra vez estas son las formas de la infancia para escapar a la severidad del juicio. De ahí que la infancia sea lo más serio de la vida, pero como tal, solo puede observarse cuando la vida se ve eclipsada por la gravedad del juego de los niños, por «el decisivo instante de la libertad» al cual Cueto le otorga la divisa de la distinción:

Cuando juega, el niño está solo; no solo consigo mismo, sino a salvo de la soledad de sí, excluido de sí por la afirmación, arrastrado a la vertiginosa inmovilidad de una alegría indiferente y sin testigos, alegría imperceptible que acaso constituye la verdadera seriedad de la existencia. (94)

Nada más trivial entonces que la infancia — pura distracción, pura atención desinteresada, puro tiempo sin el aplastante pasado ni el angustiante futuro, y aún más, por momentos puro furor atrapado en el cuerpo de un adulto que procede ligero tras los pasos de comedia que la infancia le dicta-; y, sin embargo, en lo trivial se afirma la impersonalidad de lo único: el abanico de lo ridículo que solo Los tres chiflados pueden desplegar al querer resolver trivialidades del mundo que, en verdad, no hacen más que evidenciar ese loco ritmo sin causa ni fin de lo que simplemente acontece. 
Pero ¿qué es lo que acontece en ese preciso momento en el cual el sentido falta, en ese relámpago que pulveriza la lógica con el rayo del absurdo, en ese instante en que no puede pasar otra cosa más que volar pasteles de aquí para allá hasta terminar todo en la indistinción del enchastre que el humor convoca? En el cuerpo envejecido de Bouvard y Pécuchet —en esa santidad de la infancia que no se aplica a nada que suponga un paso hacia la madurez, un juicio severo en relación con el mundo que se detesta - el pensamiento se vuelve verdadera pasión al ahondar en la estupidez. Ambos, acaso humoristas de una fase ya final, piensan por medio de la estupidez, o tal vez abisman el pensamiento en ese destino: el de dos idiotas. Como señala Cueto: «la lucidez es el desamparo del pensamiento fascinado por la estupidez» (72); por lo tanto, quien pretenda pensar hasta el final sólo encontrará la inconsecuencia y la ridiculez de todo principio, de todo fundamento inamovible, aunque tambaleante; por lo tanto, la estúpida lucidez solo puede ser predicada por la liturgia del sacerdote o la atención al juego que el niño una y otra vez intensifica. Se trata del humor ligero - la empresa de dos idiotas, los caprichos de todo niño— que punza su aguijón crítico - la denuncia del pensamiento vuelto utilidad - en el corazón mismo de lo moderno: el hastío burgués, la decadencia del largo sueño de la ilustración; pero su carcajada o su zumbido se mezcla con la música del desastre hasta volverse imposible de escuchar, pues es un hacer que es deshacer, una obra que no es más que desobra, algo que no busca más que «llevar lo irrisorio hasta sus últimas consecuencias: hasta la embriaguez, el delirio, el vértigo» (82). En ese fondo del humor lacerante, en lo último que se podría pensar, el humor como estilo señala que «la crítica no denuncia la estupidez, permite que la estupidez se denuncie, que el conocimiento se abisme en ella, que ella ascienda en el conocimiento —para que un pensamiento sea posible» (9o).

\section{VI}

La música podría ser el punto de mayor desenfreno para el humor, como de alguna manera el silencio lo es para la mera opinión, ya que en él la sintaxis se empuja hacia el estilo, en él se ubica el lugar de agotamiento del lenguaje; en definitiva, en el silencio lo que escribe no es más que lo que queda luego del fin irremediable de las palabras. Como el gato de Cheshire lo que desaparece deja un resto de sí en lo más singular: la música silenciosa de su sonrisa. La música es entonces aquello que el pensamiento no puede abandonar, la música es «la forma de lo irremediable» (15), algo así como un lugar adonde fascinación y decepción se tensionan mutuamente. Y es que solo la música puede convocar lo imposible y lo vulgar, tanto como deseo y huida o como negatividad silenciosa que se vuelve afirmación que nada dice. La música sería lo que queda luego de la risa estrepitosa de quien se aplica a pensar la rosa o la cosa y ya no distingue el punto adonde estas se disciernen en tanto una u otra; la música sería el nivel más hondo de la tristeza como desdén, cuando nada se resuelve y todo se hunde en la mudez; pero, sobre todo, la música es desmesura, la que el poema sólo alcanza cuando el sentido ha sido desplazado por las palabras. Una vez más, ante la lectura la desaparición y la radiante sonrisa, nada más. Por lo tanto, existe un pensamiento de la música o una música que permite pensar, no como simple reducción, como contraste accesible a eso que se puede plegar y desplegar hasta el infinito en el espacio y el tiempo, en la simple comparación, el como si del pensamiento en el proceder de la música; en realidad existe un pensamiento de la música en tanto que existe una pasión del pensamiento, pues la música conduce a la pasión, hace de su fuerza una forma, del mero impulso la posibilidad de una intelección: 
La fuerza es la obertura de la aseveración. Ahí tiene lugar el pensamiento (...) La forma evita que la fuerza se derrame en lo informe, se abandone a la debilidad de la expresión; pero la fuerza impide que la forma se estilice, se adelgace hasta la mera elegancia. La forma es la forma de la fuerza y la fuerza es la fuerza de la forma. La fuerza de la forma y la forma de la fuerza definen lo que se llama la seriedad de la música de Brahms. (2010:41)

Al igual que Hölderlin o Benn hay un ritmo que sostiene el mundo, en ese ritmo el hombre se compadece, por supuesto no del mundo sino de sí mismo y consigo mismo vuelto un elemento más, pues no hay nada que explicar, hay que seguir, marcar, hallar el propio ritmo para ejecutar una forma de pensamiento, la duración en el tiempo de la estúpida lucidez, o el despliegue en el espacio de la partitura del desasosiego que se experimenta al pensar. Dicha pasión solo el arte la descubre; y al descubrirla eleva el pensamiento a la categoría de lo serio «una manera, tal vez la única manera, de estar en el mundo» (47) señala Cueto. Al igual que Flaubert que buscaba palabra tras palabra un arte sobre nada, que pretendía los valores de la poesía en la novela, pero a través del camino de la prosa, el pensamiento desea esa música desmesurada, esa pasión del ritmo en la que nada se explique porque la razón de lo que es, es el simple transcurrir, el devenir de fuerzas y la aparición de formas. Pero el deseo de lo desmesurado implica también un resguardo ante ello. ¿Cómo evitar la intemperie de lo irremediable? ¿De qué modo encaminar lo desbordante? ¿Cómo hacer con lo sublime una retórica? A través de la música se puede seguir el anhelo de ese arte sobre nada, una nada que desplaza al mundo, lo eclipsa, hace por momentos que se olvide su vulgaridad, el flagelo de su reducción mimética, el tener que decir de algo su obscena presencia antes que el simple decir nada que es su goce, el disfrute de una idea sustentada en su puro ser. Desde el romanticismo el paradigma pictórico ha sido reemplazado por un paradigma musical que opera sobre las imágenes; en tal relevo, señala Cueto,

lo importante ya no es entonces su nitidez inmóvil si no su ambigua movilidad, el desplazamiento imperceptible — sosegado o violento — de unas a otras, de las unas a las otras; lo importante no está ya en la imagen misma sino en el devenir de lo imaginario, en el cauce no visible donde destella por momentos la visibilidad. (1993:27) 11

Aquí la visibilidad no es tanto lo que se ve, el límite de cualquier objeto, su brillante circunferencia; sino más bien su deseo de forma, lo perfectible que descansa en todo deseo de hacer, pues «la perfección debe ser entendida como la "construcción” de lo indefinido, es decir, también, como la indefinición de la construcción; en una palabra, como el construir: puesta en obra infinitiva de lo no-finito». Liberada del paradigma de la imagen, siendo una construcción abierta a lo indefinido, la música transcurre al margen de lo que evoca, por arriba o por debajo de su emoción en relación con la cosa; melodiosa o disonante, transparente u opaca, ella es más que eso ahí en el mundo; diáfana y fluida, «ella dice lo que dice, y este decir sin embargo permanece secreto» (29).

El decir secreto de la música es un simple advenimiento. Pero un advenimiento que, si bien es inmediato - pura percepción, puro escozor de los sentidos - también es espera, presente que aún no se afirma, presencia que se sustrae. Sin embargo, la música está ahí, nos desnuda de todo lo arraigado en nosotros: creencias, ilusiones, expectativas, todo se disuelve ante su decir secreto. La música nos abandona en nosotros señala Cueto; pero se trata de un abandono en el cual ni 
siquiera podemos distinguir un yo, no estamos en él ni acompañados por nosotros mismos; lo que irrumpe entonces es esa paradoja de la música como lugar del abandono: «la música se escucha en mí como lo que yo no puedo escuchar». Y, aun así, para que la música sea advenimiento debe llamar necesariamente a otro si queremos que lo imposible de escuchar sea al menos una experiencia: «Llamo a veces a otro a que escuche conmigo, es decir, llamo al otro en ti, como pretendiendo olvidar por un momento que él no vendrá, no volverá a venir, no habrá venido nunca sino como la soledad de la escucha, que es la soledad de la música» (2010:33). En tal soledad, música, pasión y melancolía propugnan el sueño de «un arte sin mundo», no como evasión, sino más bien todo lo contrario, como aseveración, pues el alejamiento del mundo conduce hacia la música, nos arroja a las aguas de la severidad: «La música es una aseveración melancólica. Es la severa melancolía de la música de Brahms» (35). Podríamos decir así que la música evita el naufragar propio de la melancolía, hace de su fuerza evasiva una forma de apropiación, sostiene lo invisible - como pregonaba Höldelin-. Del mismo modo entonces la sintaxis lo hace con el borramiento del sentido que acontece en el poema, pues, para Cueto, «la música y la poesía encuentran su común esencia en la sintaxis». A rigor de verdad un poema no es más que una operación abstracta de la sintaxis que ha despojado a las palabras de sus usos cotidianos arrojándolas a la trivialidad de un ejercicio como lo es la poesía; nada hay por detrás de ellas, salvo la figura del reunir que las contiene, tal vez por eso, tanto Flaubert como Mallarmé pensaron el lenguaje cual una arquitectura del instante en donde, pasado y futuro, jamás se ven abolidos, y por ello, si todo cabe en ella bajo el signo de la indistinción es indudable que en dicha construcción no hay nada. Ese extremo de la abstracción, al que Cueto denomina «construcción en movimiento», es ya la música, pues «la música del poema la oímos en su sintaxis», y, en el mejor de los casos, ella es «el único sentido que en el poema se afirma» (37). Por lo tanto, ¿qué hay en las cosas al ser motivo de interrogación por parte de la literatura? ¿Qué contesta a la atenta lectura cuando esta interroga? En las cosas interpeladas por la literatura, no hay otra cosa más que su instante de reunión en el estilo, la música de su sintaxis en la cual devienen como tales.

Así toda sintaxis es una construcción. Por lo tanto, en la literatura el oído se aplica a develar su música. Para Cueto la música es más que el furor perceptivo; en realidad la música estructura, dispone, despliega el ser paradójico que asola a la literatura, y que, en el caso de Kafka, por ejemplo, alcanza su punto más alto. Así lo que Cueto denomina «la construcción de la soledad» (2009:35), no es más que un modo de ser de la literatura y, como tal, apunta a «escribir sin escribir» (11) en esa tensión adonde, o bien «se escribe la imposibilidad de escribir», o bien no se escribe en absoluto para afirmar dicha negación. He aquí la desgracia como imposibilidad de decir; pero he aquí también la música como desvelo del pensamiento para el artista que, en su vigilia, estructura en la paradoja una vida de cantante sin cantar, una vida de acrobacias en la más absoluta inmovilidad, una vida que, como tarea, es repliegue en el pensamiento, y, para ello, debe descender en sí misma, debe despojarse hasta de la vida misma bajo el peso de una lápida, lo que equivale a, en esa profundidad silenciosa, «abrir galerías, pasadizos que exponen la intimidad al afuera»; en definitiva, entender que «la construcción es una madriguera» (36). En esa madriguera, lejos de los ruidos que abundan en el mundo, en la oscuridad de la construcción «es la música la que hace silencio» para evitar el arrebato de los sentidos. Este hacer de la música de Kafka, que Cueto llama «amusicalidad» (38), es ni más ni menos que la fuerza que resiste a la disolución impuesta por la música, y desde ya, es doblemente música pues primero es el silencio de las sirenas y luego la astucia en las 
amarras de Ulises atado al mástil de su nave. La música como construcción no es más que su propia abolición, es un retorno a la quietud de la alegría y la infancia en tanto que «la música devuelve el ruido al silencio, lo hace oír desde el silencio y hace oír el silencio que es su reparo, es decir su misma intemperie convertida en habitación» (39).

Kafka habitó la construcción de una música nunca antes escuchada; ella comenzaba en la noche con los ruidos del piso de abajo, el pasar de algún transeúnte a los pies de la ventana, las preocupaciones propias del apartado, el incapacitado sentimental, el talento oculto en la burocracia de los seguros ante los riesgos del trabajo; finalmente, la música devolvía cada uno de estos murmullos al silencio del escritorio que lo encadenaba a su posesión demoníaca: escribir para demostrar que es imposible hacerlo, aunque fuera el único modo de elevar la vida, de sustraerla al mundo pues «de esta vida sustraída al poder de vivir, de esta vida sin vida brota la desbordante, luminosa, loca alegría de la literatura de Kafka» (50). Es indudable que Cueto lee en él el paradigma de un escritor sentado, una sensibilidad atenta a lo inmóvil en el movimiento de la música que envuelve a las cosas. Pero esa envoltura no es solo la quietud, el distraerse en lo mismo, la máxima atención del quietismo, sino también su igual en su reverso: el paseo, ese otro modo de residir en el movimiento, de encontrar la propia música del estilo en lo insignificante, ya que «pasear es una forma de estar sentado» (2018:68). Tal vez por eso los ensayos de Cueto recorren una y otra vez la comarca delimitada por los intereses de su literatura; he aquí que, atentos a ese movimiento insistente, a ese puñado de autores visitados una y otra vez, habría que pensar estos ensayos como los paseos de aquel que no se mueve de su casa, y, sin embargo, conoce el mundo en unas pocas cuadras tras la atención a las minucias del barrio. Y es que la paradoja del movimiento en la quietud habilita volver una y otra vez a la literatura en busca de su distinción; en ese caso, el ensayo en Cueto no es más que una música insistente que evidencia aquello que la distingue: el carácter de impromptu sobre un viejo tema que una y otra vez se ejecuta. Pero deberíamos señalar también que nada más lejos en esta escritura que una escritura de circunstancia, pues el ensayo se escribe por sustracción, reticencia, por la constante irrupción de lo propiamente intempestivo: la soledad. Mientras todos pasean por el centro de lo grave, él se desplaza en la silenciosa displicencia de los arrabales, en la levedad de una decisión como lo es el deseo de apartarse:

Pasear puede ser un impromptu o una variación, una ocurrencia o un hábito, pero es siempre una decisión, una resolución que seguramente llega desde más allá de toda iniciativa pues supone arrancarse no solo de los ambientes sofocantes y la promiscuidad de los interiores, no solo de la familia, de toda la vida privada con sus lazos y ataduras, sino del propio yo como nudo de relaciones. (70)

La música lleva entonces a la intimidad de las cosas, al lugar adonde estas comienzan como tales, ya sea en la residencia perdida de un estar alrededor de ellas o lejos y distante en el olvido que las asalta; por lo tanto, si pasear es acompañara a las cosas en su movimiento, tal vez escribir no sea más que inventar la quietud de un silencio melancólico que, en la atención de quien escribe, se acerca a dicha intimidad. 


\section{Notas}

1 El mundo visto por primera vez resulta una experiencia del orden de lo imposible; en todo caso la simulación más próxima a esta imposibilidad podría ser el mundo visto como nunca hasta entonces se lo ha visto que no es necesariamente una ficción de origen, sino más bien un desplazamiento hacia el estilo como manera absoluta de ver las cosas, tal como Flaubert lo quería para su Salambó o su heroína de provincia. Parte de la originalidad del ensayo, sobre todo en su ejercitación solitaria y en su búsqueda de una autonomía radical, se funda en un proceso de extrañamiento de las cosas que es a su vez la intimidad misma de las cosas; que es también esa cercanía perdida, la soledad que puede habilitar lo insignificante próximo, el interrogante en la apariencia de una ausencia absoluta de interrogantes. Rareza de la forma, pero también rareza en la atención de quien mira; en fin, ambas se juegan como distinción futura del ensayista. La escritura de Cueto ha visto como nunca hasta entonces el humor, la risa, el gag, las paradojas, una caminata por la ciudad de todos los días, la permanencia en la casa, el lento trabajo de las ideas, unas botellas en un tapial, la música en la prosa donde el retiro de la música ha sido su silencio y como tales, estas son las señas de su distinción ensayística.

2 La expresión pertenece a Juan Bautista Ritvo: «Todo el proceso de pensamiento consiste en, antes que nada, sumirse en el fondo de lo que carece de imágenes, abandonarse a él por un instante, abandonarse a un proceso cuyas fuerzas vagas e inconsistentes no se han cristalizado aun en seres y cosas determinados, abandonarse a ese fondo que oscila entre el silencio y el ruido, pese a lo cual, paradójicamente, ese fondo es a la vez fundamento, id est, principio de razón insuficiente» (2018:123).

3 «El ejercicio estará, está encaminado, pues, a encontrar el acuerdo, la conformidad con lo que es. Se trata de que lo que es no sea un estorbo sino precisamente lo que es. Se trata de habitar lo que es tal como es (...) Es necesario que el ejercicio se atenga al presente, haciendo de él nada más que el instante de la aceptación, de la aseveración perseverante de lo que es» (1993:107).

4 El ejercicio para ser una realización debe ser al mismo tiempo una negación, una suerte de movimiento paradójico, el cual Cueto sintetiza como una práctica sin práctica: «El ejercicio no persigue un fin exterior a su práctica ni tiene a la práctica como su propio fin. La práctica no es distinta de la realización, la realización no es diferente de la práctica. Como la realización está en la práctica, la realización no tiene fin; como la práctica constituye la realización, la práctica no tiene principio. El ejercicio es una práctica sin principio ni fin» (2009:59-60).

5 Habría que entender también el estilo como la afección de una pasión; la pasión propia de la escritura y el pensamiento, que no solo disuelve el mundo en su deseo de forma, sino que también se disuelve a sí misma en la presumible verdad a la que llega. Así como la ociosidad es un principio en Bouvard y Pécuchet que da inicio a su estúpida obra, también termina siendo una pasividad, un obrar negativo: «La holganza no obra, pero "desobra", y este desobrar no tiene nada de negativo, es la puesta en obra de la monotonía, la "forma" de la monotonía en la obra. La monotonía es el perpetuo recomienzo que engulle o rompe, anula y torna inútil, desalienta y finalmente impide todo comienzo (...) Pero en la ociosidad opera ya, discreta, silenciosamente, el "obrar" de la holganza o la desobra. La desobra es el hacer del no-hacer» (1999:86).

6 Tal degradación no siempre supone un sujeto en relación con ese objeto, en determinados casos la obcecación y el estancamiento de la atmósfera hacen de las cosas objetos de una opacidad intransitiva: «El objeto ya no se trasciende en otros objetos: no se articula en un plexo de útiles (inservible, rompe la red de la utilidad), ni en una serie causal (carece de causas y no produce efectos), ni en una estructura de sentido (se ha vuelto insignificante y lo contamina todo de insignificancia); abismado en su sitio, en la pura satisfacción de sí mismo, se desata de todas las relaciones a las que estaba ordenado y, desasido de este modo, resbala y cae fuera del horizonte que lo refería a la necesidad humana; no insatisfactorio sino más bien indiferente, hace ascender ese excedente de satisfacción que no encuentra necesidad alguna, que no puede aplicarse a nada y que se suele llamar hastío, o más bien hartazgo» (1999:68).

7 La intransitividad del poema puede entenderse también como un extremismo de la forma. Cueto señala en la poesía de Girri una aspiración a lo inmaterial del sentido que parte de la pintura, entendiendo el poema como rostro, paisaje o dibujo, y llegando hasta la mismísima música, en donde se puede entender el poema como sintaxis: «Por eso el poema tiene un rostro, o un paisaje, y se puede hablar del poema como dibujo. Pero el espaciamiento de los párrafos resulta del movimiento de construcción de la frase, es decir de la línea única y sin dimensiones de la sintaxis. Plásticamente, está inmóvil, pero la inmovilidad no 
es un estado sino el lugar de su estancia. La estancia es el movimiento del poema. Ese movimiento que se mueve infinitamente en su inmovilidad es el movimiento de la sintaxis. El movimiento de la sintaxis es la música del poema» (2010:76).

8 Cabría señalar que en este y otros puntos la lectura de Cueto ha hecho de la opacidad y la dificultad asignadas a Girri —el endilgado no lirismo de lo arduo- la virtud misma del ejercicio: «Por eso el ejercicio consiste para la lírica en despojarse de todo lirismo, es decir, de todo impulso emotivo, toda vaguedad y divagación imaginarias, toda adjetiva belleza. La lírica se torna prosaica, pero no por eso se convierte en prosa» (2010:78).

9 Es en Kleist donde Cueto lee la presencia de una gracia del humor, la cual no es más que «un efecto heterogéneo a su causa», la pura inconsecuencia de una eficacia sin finalidad a la que podemos llamar don o ejercicio. Su práctica no busca más que una ciencia de la inocencia, a la cual «le damos el nombre de necencia. La necencia es una ciencia sin ciencia — sin reflexión ni intención ni representación, es decir sin conciencia-. Desde el punto de vista de la conciencia la necencia no es más que necedad. Pero lo mismo cabe decir desde el punto de vista de la inocencia. Necio no es el hombre de ciencia, rigurosamente consciente, ni el niño o el animal, solamente inocentes. Si la necencia consiste en volver con ciencia a la inocencia, es decir en aprender a no-saber, querer el no-querer, hacer sin hacer, entonces auténticamente necio solo puede serlo el humorista, pues la necencia es nada más que humor» (74).

10 Habría que pensar también la infancia, desde una figura de la paradoja, como una forma de resistencia por medio de la impotencia: «Desde el punto de vista educativo, la infancia representa a la vez la impotencia en el mundo y la potencialidad inagotable del mundo. La infancia es potencia de madurez y la madurez es el acto de resolución de la potencia y el poder de eliminación de la impotencia infantil. Si la potencia se resuelve en el acto, la impotencia es lo que el acto elimina pero no se apropia. El poder —aquí en particular el poder de la educación— no puede nada con la impotencia. La impotencia es lo que queda de la infancia en el mundo adulto» (2009:67).

11 Los destellos momentáneos de la visibilidad pueden entenderse también como la experiencia de habitar la tierra baldía de la modernidad: «Lo sorprendente de la tierra baldía es que está desierta de lugares, pero atiborrada de espejismos, vacía de cosas, pero llena de imágenes. Nadie puede habitar una imagen. Una imagen no puede ser otra cosa que una invitación al viaje» (2018:66).

\section{Referencias bibliográficas}

Cueto, S. (1993). Seis estudios girrianos. Rosario: Beatriz Viterbo.

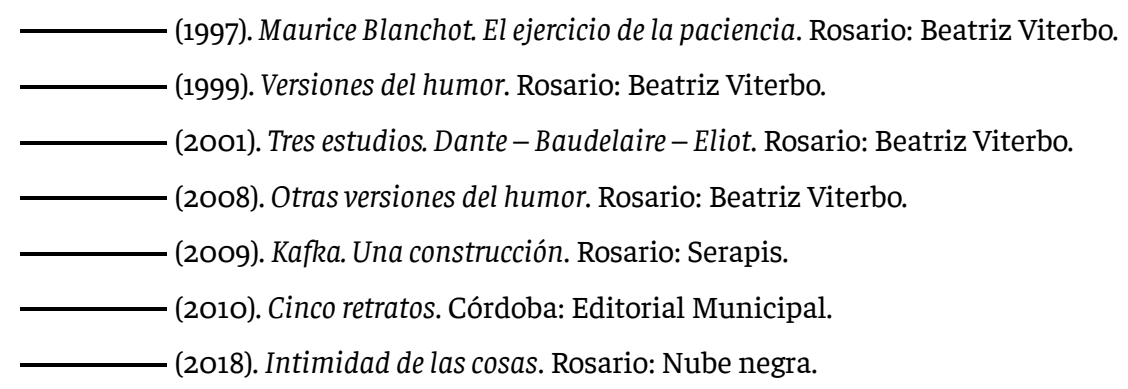

Ritvo, J.B. (2018). La imagen sustraída. Rosario: Otro cauce/Nube Negra. 